\title{
Afetlerde START Triaj Skalası
}

\author{
Galip Usta ${ }^{1}$,, Kemal Torpuş², Uçar Küçük
}

${ }^{1}$ Artvin Çoruh Üniversitesi, Sağlık Hizmetleri Meslek Yüksekokulu, İlk ve Acil Yardım Programı, 08000, Artvin ${ }^{2}$ Artvin Çoruh Üniversitesi, Artvin Meslek Yüksekokulu, Sivil Savunma ve İtfaiyecilik Programı, 08000, Artvin.

\section{Özet}

Afetler insanoğlunun var olduğu günden itibaren görülen olaylar döngüsüdür. Eski kayltlar incelendiğinde dünyanın farkl yerlerinde meydana gelen çeșitli afet türlerine ilișkin verilere rastlanmıștır. Afetler meydana geliș zamanları belli olmayan ve sürekli hazırlıklı olmayı gerektiren durumladır. Afet öncesi çalışmalar ne kadar iyi yapılırsa yapılsın afetin oluşmasını engellemez, fakat afetin doğurabileceği olumsuz sonuçları en aza indirmede büyük katkı sağlar. Bu bağlamda hazırlıklı olma planları kadar, oluşabilecek olaylara müdahale etme planlarl da önem arz etmektedir. Meydana gelen olaylar sonrast, yaralılara zamanında, doğru ve etkili müdahale işleminin gerçekleştirilmesi ölüm oranını en aza indirdiği gibi sağlıklı să̆ kalım oranını da artırmaktadır. Yaralıların yaşamlarını tehdit eden olaylara veya yaralanma önceliklerine göre doğru șekilde sinıflandirılması, transportunun sağlanması, acil bakımın her bireye ulaştırılması triajda ana hedef olarak seçilmelidir. Yani eldeki sınırlı imkânları kullanarak çok sayıda yaralı için en faydalı olanı yapmaktır. Başarılı bir şekilde gerçekleștirilen triaj ișlemi sağlık ekiplerin müdahale başarısını artırdığı gibi, olay yeri yönetiminin sağllkl yürü̈tülmesine de zemin hazırlamaktadır. Bu çalışmada, kitlesel olaylarda kullanılmak üzere belirlenmiş ve kabul edilmiş, "Simple Triage And Rapid Treatment" sözcüklerinin baş harflerinden oluşturulmuş START skalası hakkında bilgi verilmesi amaçlanmıştır.

\section{$\underline{\text { Anahtar Sözcükler }}$}

Afet, Triaj, Start Skalas1

\section{START Triage Scale in Disasters}

\begin{abstract}
Disasters are events that occur since the beginning of time. When previous records are investigated, information on various types of disasters occurred in different parts of the World are encountered. Disasters occur unexpectedly and require constant state of preparedness. No matter how extensive the precautions are, disasters cannot be prevented, but the precautions significantly contribute to the reduction of negative consequences to a minimum. In this context, response plans to events that may occur are as important as the preparedness plans. Responding to disaster victims on time, correctly and efficiently reduces the mortality rate to a minimum as well as increasing the survival rate. Correct classification of the victims based on the life threatening events or the priority of their injuries, providing transport, and ensuring each individual receives emergency aid should be the main goals of triage. That is, to be the most helpful to as many injured people as one can by using the limited opportunities available. A successfully performed triage not only increases the success of the healthcare team's response, it also enables healthy execution of scene management. In this study, the aim is to provide information about START scale composed of the first letters of "Simple Triage And Rapid Treatment" that has been developed and accepted to be used in mass events.
\end{abstract}

Keywords

Disaster, Triage, Start Scale

\section{Giriş}

İnsanlık tarihinin var olduğu günden itibaren afet olayları meydana gelmektedir. Eski kayıtlar incelendiğinde, dünyanın farklı yerlerinde meydana gelen çeşitli afet türlerine ilişkin verilere rastlanmıştır (Erkal ve Değerliyurt 2009). Devletler tarihsel gelişimine, ekonomisine, siyasal ve sosyal durumuna uygun bir yönetsel yapıya sahiptir. Tarihimize baktı̆̆ımızda çeşitli afetlerin meydana gelmiş olması, geride bıraktığımız yılları "afetler yüzyılları" olarak hatırlamamıza sebep olmaktadır (Yavaş 2001).

İnsanlar ve diğer varlıklar için fiziksel, ekonomik ve sosyal kayıplar doğuran, normal yaşamı ve insan faaliyetlerini durduran veya kesintiye uğratan, etkilenen toplumun baş etme gücünün yetersiz kaldığı doğal, teknolojik veya insan kaynaklı olaylara afet denir. Kısaca afet; bir olayın meydana gelmesi değildir, doğurduğu sonuçtur (Kadığlu 2008). 
Afetler toplumların sosyal yaşantılarına, yaşam tarzlarına, konutların mimarı tasarımlarına yönelik değişimleri beraberinde getirir. Afetin tanımı kaynaklara göre çeşitlilik göstermekle birlikte en yaygın biçimde yapılan afet tanımının öğelerini aşağıdaki parametreler oluşturmaktadır:

- Ekolojik denge yapisının bozulmasi,

- Olağan yaşamın bozulması,

- Can ve mal kayıplarının meydana gelmesi,

- Sorun ile mücadele etmede toplumun yanıt kapasitesinin yetersiz kalmasi,

- Toplum olarak dış yardıma muhtaç kalınması

Afet tanımını oluşturan temel öğeler göz önüne alındığında bir olayın afet olarak nitelendirilmesinde iki ana tema göze çarpmaktadır. Bunlardan birincisi, toplumun meydana gelen afetin sonuçlarıyla mücadele etmede yetersiz kalması, ikincisi ise dıș kaynaklı yardıma ihtiyaç duyulmasıdır (Eryılmaz ve Dizer 2007).

Afetlerin önlenmesi, zararlarının azaltılması, afetlere hızlı ve etkili bir şekilde müdahale edilmesiyle birlikte, etkilenen topluluklara güvenli ve sağlıklı yeni bir yaşam çevresi oluşturulabilmesi için toplum tarafından gerçekleştirilen topyekûn mücadele süreci afet yönetimi olarak adlandırılmaktadır (URL-1 2017). Bütünleşik afet yönetim süreci afet öncesi ve afet sonrası çalışmalar olarak nitelendirilir. Afet öncesi çalışmalar; hazırlık, zarar azaltma ve önleme basamaklarından, afet sonrası çalışmalar; müdahale ve iyileştirme basamaklarından oluşmaktadır. Modern afet yönetim sisteminde afet sonrası uygulamaların yerini afet öncesi çalışmalar alarak afete karşı dirençli toplum oluşturulması planlanmaktadır. Bu aşamada toplum eğitimi, yapısal ve yapısal olmayan zararların azaltılması ve erken uyarı sistemlerinin geliştirilmesi gibi konulara yönelik çalışma yapılmasının gerekliliği vurgulanmaktadır (URL-2 2017). Afet yönetiminin aşamaları kendi aralarında doğrusal değil, döngüsel bir ilişki içerisindedir. Bütünleşik afet yönetim sistemi basamakları Şekil 1'de verilmiştir (Macit 2016).

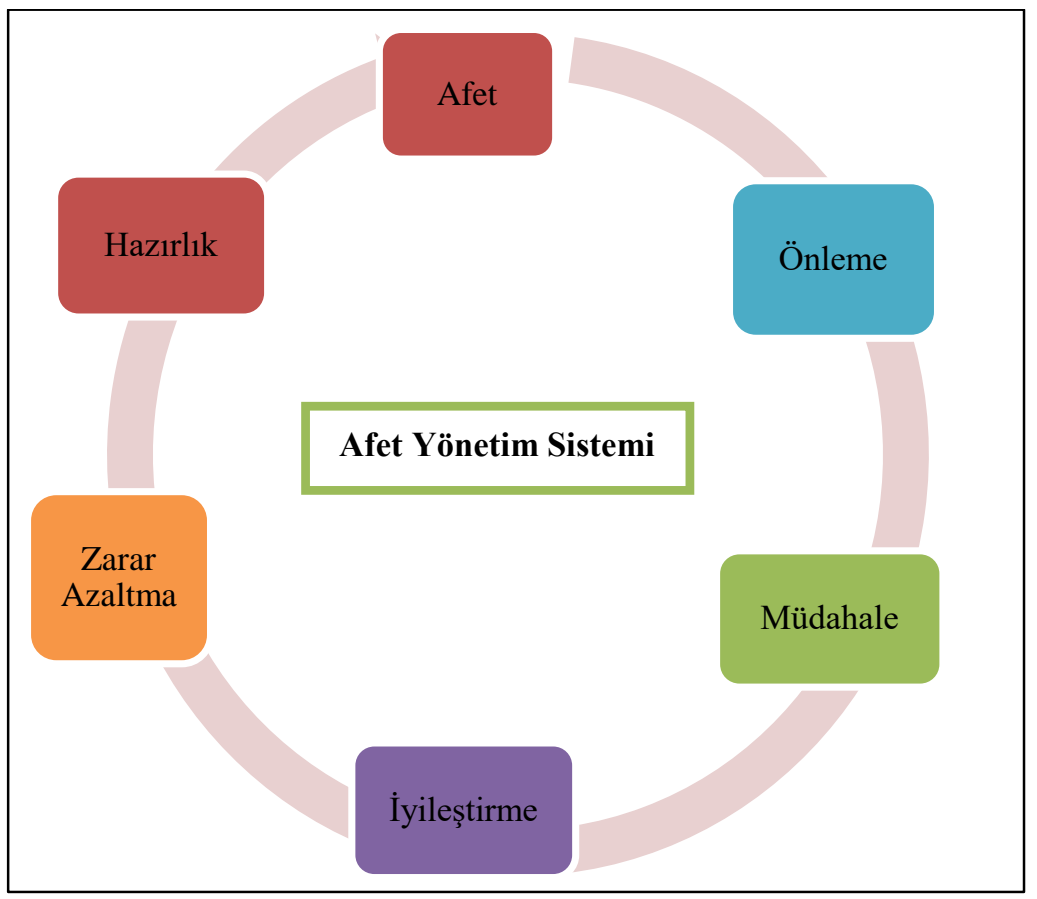

Şekil 1: Afet Yönetim Sistemi (Özmen vd. 2005; URL-3 2017).

\section{Afet Yönetim Sisteminin Basamakları}

\subsection{Zarar Azaltma}

Risklerinin belirlenmesi, kayıpları engelleyici önemlerin alınması, toplumun afetler konusunda bilgilendirilmesi ile teknik, idari ve diğer önlemlerin alınarak yeni stratejilerin oluşturulmasına yönelik yapılan çalışmaları kapsamaktadır (URL-4 2017; Taştan ve Aydınoğlu 2015). Afetlere karşı zarar azaltma çalışmalarının başarısı idarenin ve toplumunun işbirliği içinde çalışabilmesine bağlıdır. İdarenin afet tehlikelerine karşı risk yönetimini genel karar alma süreçlerinden ayırmak mümkün değildir. Afet yönetiminin risk yönetimi çalışmaları sürdürülebilir kalkınmanın bir parçası olmalı ve çevre yönetimine entegre edilmelidir (Ekşi 2015).

Tehlike, belirli bir zaman ve coğrafyada ortaya çıkarak yaşamı tehdit eden, toplumun sosyoekonomik düzen ve etkinliklerine, doğal çevreye, doğal, tarihi ve kültürel kaynaklara zarar verme potansiyeli olan doğa, teknoloji ya da insan kaynaklı fiziki olay ve olgulardır. Hassasiyet ise kırılganlık ve savunmasızlık diye nitelendirilebilir (AFAD 2014). Afetin 
etkisi, tehlike ile hassasiyetin kesişimin den oluşmaktadır. Afetin etkisini küçültmek için tehlikeleri ortadan kaldıramayacağımıza göre toplumun hassasiyeti üzerinde durmamız gerekmektedir. Bu bağlamda toplumsal koşulların iyileştirilmesi afetlere karşı hazırlıklı olmanın önemli yapı taşlarından birini oluşturmaktadır (Şekil 2 ve Şekil 3) (URL-5 2017).

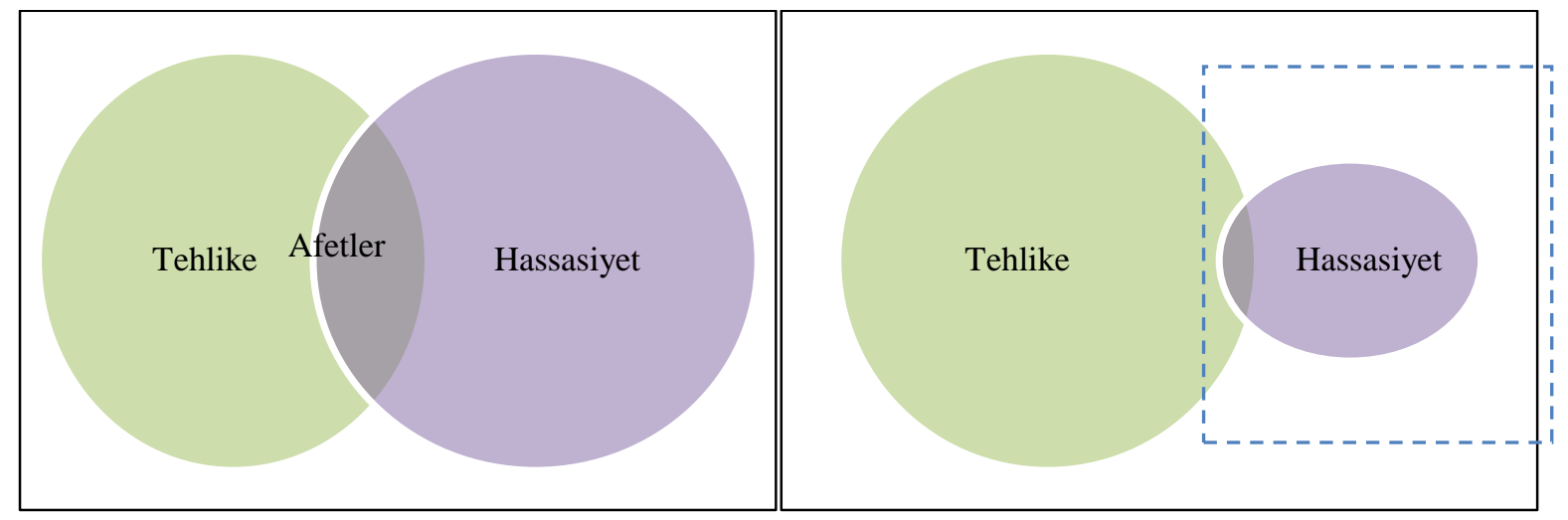

Şekil 2: Etkisi büyük afet bileşeni (URL-5 2017)

Şekil 3: Etkisi küçük afet bileşeni (URL-5 2017)

\section{2. Önleme}

Önleme; risk oluşturan bir tehdit önceden tespit edilerek, oluşmasını engellemek ya da oluşturacağı zararı en aza indirmek için fiziki, sosyal ve siyasi önlemleri içerir. Bazı afetler tamamen önlenebilir olmakla birlikte, doğal kaynaklı afetleri önlemek zordur. Bazı afetleri ise önlemek mümkün değildir. Bununla birlikte, deprem başta olmak üzere, önlenmesi mümkün olmayan doğal afetler için yönetim organizasyonu zarar azaltma çalışmaları üzerine yoğunlaşır. İnsan kaynaklı afetlerde ise etkin risk çalışmaları ile afeti önlemek ya da zararı en aza indirmek mümkündür (Ekşi 2015). Diğer bir deyişle önleme; tehlikeleri tanımlamak, can ve mal tehditlerini değerlendirmek ve bazen afeti hafifletme olarak bilinen can ve mal kayıp potansiyelini azaltmak için alınacak tedbirleri içermektedir (URL-6 2017).

\subsection{Hazırlık}

Afete hazırlık; afetlere zamanında, hızlı ve etkili olarak müdahale edebilmek için afet oluşmadan önce yapılması gereken planlama, eğitim, tatbikatların düzenlenmesi, erken uyarı sistemlerinin kurulması, acil yardım malzeme stoklarının oluşturulması, halkın bilgilendirilmesi ve bilinçlendirilmesi gibi çalışmaların sürekli ve sürdürülebilir olarak yürütüldüğü süreçtir (AFAD 2014). Farklı pencereden bakıldığında afetlere etkili ve hızlı müdahale prensibini, iyileştirme çalışmalarının planlarını içerisinde barındıran, personel, malzeme, araç-gereç ve diğer yardımların koordineli bir şekilde harekete geçirilmesi için yapılan çalışmaları içermektedir (Kadığlu ve Özdamar 2008). Planlama, afetin oluşması durumunda etkin ve hızlı bir müdahale için gerekli olabilecek eylemlerin önceden belirlenmesi ve tanımlanmasını kapsar. Planlama yapılırken ilgili her kurum planlamaya dâhil edilmelidir. Planlar belirli zamanlarda revize edilmeli ve farklılık gösteren afet türlerine karşı esnek bir yapıda hazırlanmalıdır (Ekşi 2015).

\subsection{Müdahale}

Arama kurtarma çalışmalarının triaj ve acil tıbbi müdahale işleminin gerçekleştirilmesi ile birlikte afetzedelere ileri tedavi ve bakım hizmetlerinin sunulması için transport çalışmalarının yapıldığı aşamadır. Müdahale aşamasında kamu, özel kurum ve kuruluşların imkânlarından faydalanılarak haberleşme, ulaşım, lojistik, medikal kurtarma ve koruyucu sağlık hizmetleri yerine getirilmelidir (URL-2 2017). Müdahalede; arama, kurtarma, acil tıbbi yardım, tahliye gibi faaliyetlerle birlikte afet mağdurları için barınma başta olmak üzere asgari yaşam koşullarının sağlanması gibi faaliyetler de yer almaktadır (Ekşi 2015).

\section{5. İyileştirme}

İyileştirme; afetten etkilenen toplulukların, haberleşme, barınma, alt yapı, eğitim, uzun süreli iskân, sosyal ve ekonomik faaliyetler gibi toplumun ihtiyacının karşılanmasına yönelik yapılan çalışmalar bütünü olarak tanımlanabilir (Ertürkmen 2006). İyileştirme çalışmalarında, afetten doğrudan ya da dolaylı zarar gören tüm mağdurlara ulaşılmalıdır. İnsanların sosyal ya da ekonomik alanda yaşamlarını etkileyen tüm sistemler ve alt yapı afet öncesi duruma dönene kadar devam ettirilirken, en önemli hedef ise mümkün olan en kısa sürede toplumun yardım almaksızın tekrar kendi kendine yeterliliğinin sağlanması olmalıdır (Ekşi 2015). Afetin hemen sonrasında yani kısa vadeli dönemde temel ihtiyaçların 
giderilmesi ve kısa süreliğine geçici barınak hizmetlerinin sunulması önem arz etmektedir. Uzun vadeli aşama ise bir felaketin daha ciddi veya kalıcı etkilerini gidermek için iyi bir stratejik planlama ve eylem gerektirir. Ekonomik çeşitlilik kazandırma, yeni kaynaklara ulaşmak, yeni ortaklıklar kurmak ve etkili iyileştirme stratejileri ve taktiklerini uygulamak için ekonomik kalkınma kapasitesinin geliştirilmesi için yeni yatırımların yapılması önemlidir (URL-7 2017). Kalıcı iskânların oluşturulması için gerekli alt yapı ve kentsel dönüşüm çalışmaların uzun vadeye yayılmış bir stratejik plan üzerinden yürütülmesi gerekmektedir.

\section{Afetlerde START Triaj Skalası}

\subsection{Triaj Tanımlamaları}

Triaj; hasta veya yaralıların, yaşamlarını tehlikeye düşüren yaralanma derecelerine ve beklenilen yarara göre sıralanması işlemidir. Hasta veya yaralıların acil yardım önceliklerinin hangi sıraya göre yapılması gerektiğini, zaman yönetimini, transport şeklini ve seçilecek hastaneyi belirleyen öncü bir değerlendirme sistemidir. Triaj sistemi, eldeki sınırlı kaynakları kullanmak suretiyle çok sayıda yaralıya acil bakımı ulaştırabilmek amacıyla tıbbi personel veya acil tıp çalışanları tarafından kullanılan sistemdir (Türkdemir 2016). Akıcı ve sürekli değişim gösteren bir süreç olan triaj, hastaların hangi zaman ve sırada acil yardım alması gerektiğini, transport hızını ve seçilecek hastaneyi belirleyen kısa klinik değerlendirmedir (Eryılmaz ve Dizer 2007). Triaj konusunda farklı tanımlamalar yapılmış olsa da ana hedef eldeki sınırlı kaynakları kullanarak daha fazla yaralıya fayda sağlamaktır. Etkin bir triaj uygulaması basit, hızlı, güvenilir, yanılma payını en aza indiren kabul edilmiş sistematik bir skala üzerinden yapılmalıdır (Adaş vd. 2012).

Triaj Görevlisi; olay mahalline ulaşan ekibin amiri veya görevlendirdiği kişi olarak tanımlanır (URL-8 2017). Her sağlık çalışanı aynı zamanda bir triaj görevlisi olduğu için triaj konusunda kendilerini geliştirmelidirler. Görevleri;

- Triajın etkili biçimde yapılmasını sağlamak,

- Triaj işaretlemesinin tam olarak yapılmasını sağlamak,

- Gerekli ekipmanları komuta kontrol merkezi aracılığı ile sağlamak şekline belirlenmiştir.

Olayın niteliğine ve yaralı sayısına göre farklı değerlendirme skalaları uygulamaktadır. Kitlesel olayların meydana geldiği durumlarda detaylı değerlendirme gerektiren skalalar yerine etkin, zaman kazandırıcı, çok sayıda yaralıya kısa zamanda ulaşma ve değerlendirme olanağı sağlayan basit değerlendirme skalalarına yer verilmelidir. Örneğin; az sayıda yaralıların olduğu fakat sık karşılaşılan, tıbbi imkanların etkilenmediği olaylarda START (Simple Triage And Rapid Treatment) skalası yerine daha spesifik değerlendirme imkanı sağlayan CRAMS (Circulation, Respiration, Abdomen, Motor and Speech) skorlamasına yer verilmektedir. Bu skorlama sisteminde solunum, dolaşım, batın, motor ve konuşma parametrelerine bakılarak detaylı bir hasta değerlendirilmesi yapılmaktadır. Yaralılara her parametreden belirli bir puan verilir ve toplam puana göre hasta veya yararılar gruplara ayrilarak uygun merkezlere transport edilirler. Puanlama sonucuna göre 9 ve 10 puana sahip olanlar minör travma, 8 ve altı puana sahip olanlar majör travma grubuna alınır. 6 puan ve altına sahip hasta veya yaralılar ciddi olarak değerlendirmeye alınır (URL-9 2017).

Tablo 1: CRAMS Skorlama Sistemi

\begin{tabular}{|c|c|c|}
\hline \multicolumn{3}{|c|}{ CRAMS (Circulation, Respiration, Abdomen, Motor and Speech)* } \\
\hline Dolaşım & $\begin{array}{l}\text { Normal kapiller geri dolum ve } \mathrm{SKB}^{*}>100 \\
\text { Gecikmiş kapiller geri dolum ya da SKB } 85-100 \\
\text { Kapiller deri dolum yok ya da SKB }<85\end{array}$ & $\begin{array}{l}2 \\
1 \\
0\end{array}$ \\
\hline Solunum & $\begin{array}{l}\text { Normal } \\
\text { Anormal (Eforlu / yüzeysel) } \\
\text { Yok }\end{array}$ & $\begin{array}{l}2 \\
1 \\
0\end{array}$ \\
\hline Karın & $\begin{array}{l}\text { Normal } \\
\text { Karın / göğüs ağrılı } \\
\text { Karın rijit / yelken göğüs }\end{array}$ & $\begin{array}{l}2 \\
1 \\
0\end{array}$ \\
\hline Motor & $\begin{array}{l}\text { Normal } \\
\text { Ağrılı uyaranlara yanıt } \\
\text { Yanıt yok veya deserebre }\end{array}$ & $\begin{array}{l}2 \\
1 \\
0\end{array}$ \\
\hline Konuşma & $\begin{array}{l}\text { Normal } \\
\text { Konfüzyon } \\
\text { Anlamsiz ses ve kelimeler }\end{array}$ & $\begin{array}{l}2 \\
1 \\
0\end{array}$ \\
\hline
\end{tabular}

*SKB (Sistolik Kan Basıncl), kalbin kasılma anında ölçülen kan basıncı değeri, sistol: kalbin kasılması, circulation: dolaşım, respiration: solunum, abdomen: karın, speech: konuşma, rijitide: gerginlik, katılık, konfüzyon: bilinç bulanıklı̆̆ 
Yaralı sayısının fazla olduğu kitlesel olaylarda amaç en kısa sürede en fazla yaralıya ulaşmak ve yaralıların durumlarına göre birincil sınıflandırmayı yaparak ileri acil bakım için transport hazırlıklarına başlamak olmalıdır. Bu durumda zaman kazandırıcı, kolay, etkin uygulanabilen sistemlerden START triaj skalasına yer verilmelidir (URL-9 2017). START, Simple Triage And Rapid Treament (Basit Triaj ve Hızlı Tedavi) sözcüklerinin baş harflerinden oluşturulmuştur.

Triaj işlemi bir kodlama sistemine göre düzenlenmektedir. Dünyada triaj kodlamaları değişiklik gösterse de sonuç ve değerlendirme mantığı aynıdır. Ülke olarak Acil Tıp Birliği’nin kabul etmiş olduğu Emergency Medical Service (EMS) renk skalasını kullanmaktayız. Bu triaj kodlaması dört ana renk üzerine kurulmuştur (URL-10 2017).

\subsection{Triaj Renkleri}

EMS renk sklasında kırmızı renk birinci öncelikli taşınması gereken hasta gruplarını belirtir. Bu gruba giren hastalar ivedi bir şekilde tedavisi yapılmalı ve sevk edilmelidir. Sarı kodlu hastaların kırmızı kodlu hastalara göre bekleme süresi biraz daha fazladır. Sarı kodlu hastaların transport işlemi zamanında gerçekleşmezse sağlıklı să̆ kalım oranı düşer. Yeşil; yürüyebilenler, acil bakıma çok fazla gereksinimi olmayan, bilinci açık hasta veya yaralı kişilerdir. Bu kişilerden bazıları kurtarıcılara yardım etmek için değerlendirilebilir. Siyah kodlular ise ölmüş ya da ne kadar müdahale edilirse edilsin hayatta kalma şansı çok düşük olan yaralılardır. Afet durumlarında bu tür kişiler tıbben ölmemiş olsa bile siyah olarak değerlendirilir ve sağlık hizmeti verilmez veya en son sırada acil bakımı sağlanır (URL-10 2017; URL-8 2017).

Triaj işleminde bir diğer kodlama sistemi NATO (North Atlantic Treaty Organization) tarafından kullanılan harf skalasıdır. Bu skalaya göre T1 kırmızıyı, T2 sarıyı, T3 yeşili, T4 siyahı ifade etmektedir. Bazı sistemlerde ise sembol skalası kullanılmaktadır. Tavşan kırmızı renk, kaplumbağa sarı renk, yaya yeşil renk ve haç siyah renk yerine kullanılmaktadir.

Tablo 2: Harf ve Sembol Triaj kodları (URL-10 2017).

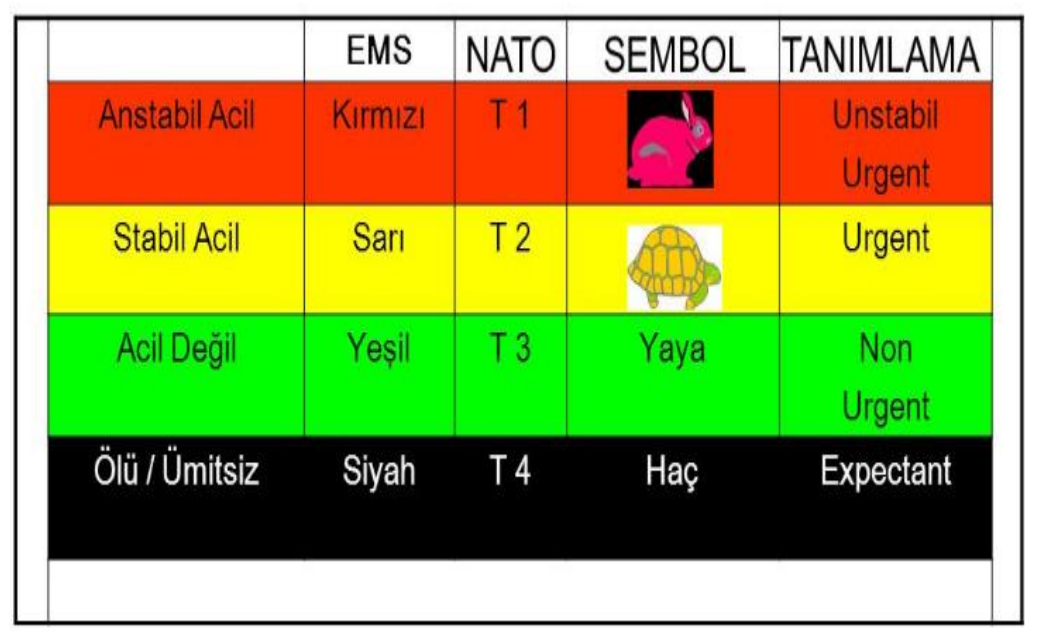

Triaj işleminde hangi skala kullanılırsa kullanılsın olay yeri güvenliği sağlandıktan sonra en yakın ve güvenilir alandan işleme başlanılır. Sesli komut sistemi ile birlikte "yürüyebilenler bana doğru gelsin" diyerek ilk ayırma işlemine başlanır ve komuta cevap verenler yeşil kodlanarak güvenli alana sevk edilir (URL-8 2017). İşlem basamakları şu şekilde uygulanır:

- Yeşil gruba giren kişiler ayrıldıktan sonra diğer hasta veya yaralıların solunum değerlendirme basamağı ile işleme devam edilir. Spontan solunum var mı? veya uygun manevra ile solunum başladı mı?

- Cevabımız hayır ise; baş boyun pozisyonu verilerek tekrar değerlendirilir. Solunum başlamış ise kırmızı kod verilir, solunum dönmemiş ise siyah kod verilir.

- Cevabımız evet ise; solunum sayısına bakılır. Solunum sayısı otuzun altında ise dolaşım kontrolüne geçilir. Solunum sayısı otuzun üstünde ise kırmızı kod verilir.

- Dolaşım değerlendirilmesi radyal nabız veya kapiller geri dolum testi ile belirlenir. Kapiller geri dolum testinde hastanın tırnak uçlarına kısa süreliğine basılır ve bırakılır. Bırakma sonrası beyazlık pembeye 2 saniye içinde dönüyorsa bilinç durumu değerlendirmesine geçilir. Dönüşüm 2 saniyenin üzerinde ise gerekli durumlarda kanama kontrolü yapılarak kırmızı kod verilir.

- Bilinç durumu değerlendirmesi komut sistemi ile yapılır. Hasta basit komutlara mantıklı cevap veriyorsa sarı olarak işaretlenir. Basit komutlara cevap vermiyorsa kırmızı kodlu olarak işaretlenir. Kitlesel olaylarda en çok kullanılan START triaj skalası Şekil-4'de verilmiştir. 


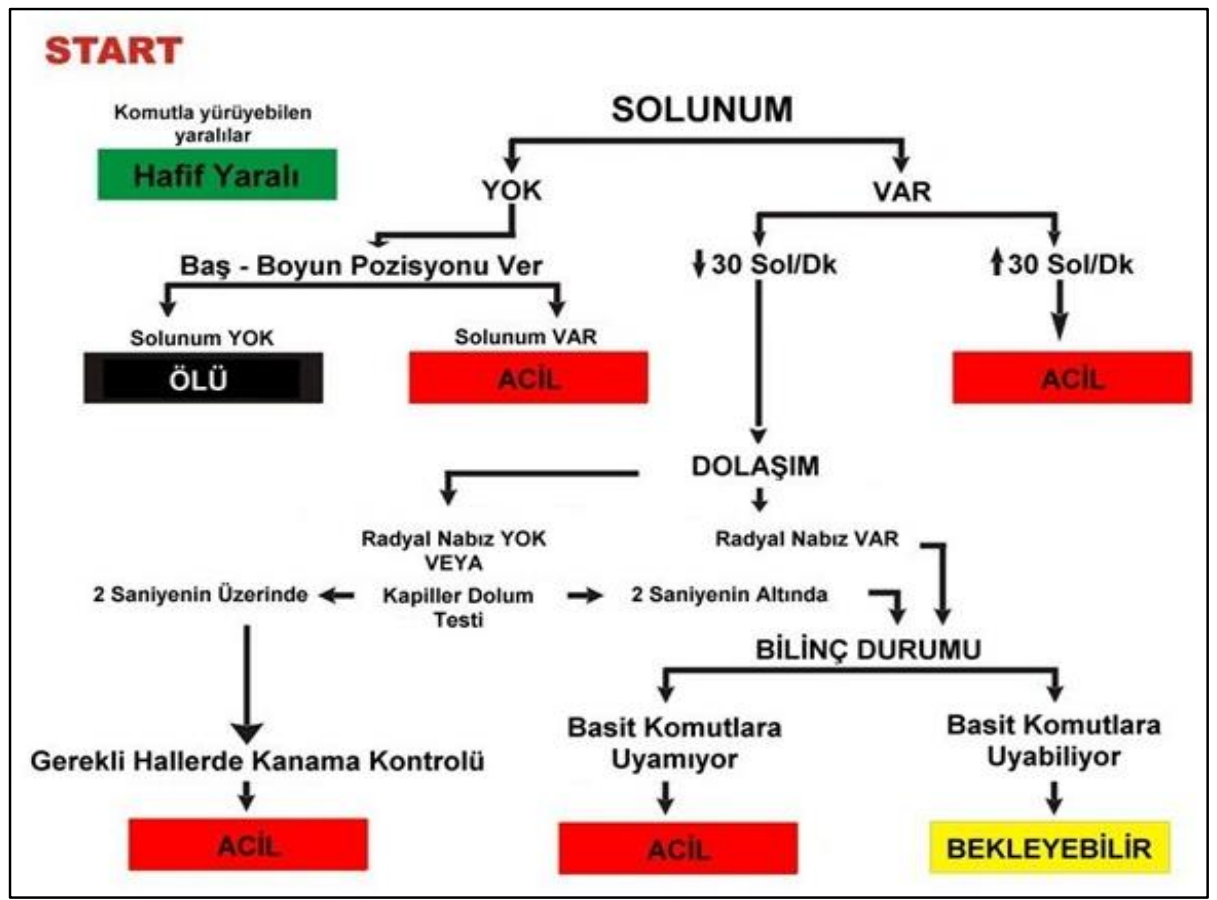

Şekil 4: START triaj skalası (URL-8 2017).

START sisteminde kullanılan değerlendirme kriterleri solunum, dolaşım, bilinç şeklinde sıralanmıştır. Bu skala yetişkin hastalar için kullanılır.

\section{Sonuç}

Bütünleşik afet yönetim süreci afet öncesi ve afet sonrası çalışmalar olarak nitelendirilir. Afet öncesi çalışmalar hazırlık, zarar azaltma ve önleme basamaklarından, afet sonrası çalışmalar ise müdahale ve iyileştirme basamaklarından oluşmaktadır. Meydana gelen afetlere zamanında, hızlı ve doğru müdahale etmek afet öncesi yapılan hazırlık çalışmaları kadar önemlidir. Olay yerinin başarılı bir şekilde yönetilmesi, ölüm oranlarının azaltılması ve sağlıklı sağ kalım oranın artırılması, doğru yaralı sınıflaması ve etkin bir müdahale işlemine bağlıdır. Bu bağlamda kitlesel afetlere müdahale aşamasında, zaman kaybı oluşturmayan güvenilir ve kısa sürede uygulanabilen START triaj skalasının etkin olacağı görülmektedir.

\section{Kaynaklar}

Adaş G., Turgut N., Akçakaya A., (2012), Büyük Afetlerde Sağlık Hizmetlerinin Planlanması Organizasyonu ve Triaj, Okmeydanı Tıp Dergisi, 28(2), 124-134.

AFAD, (2014), Açıklamalı Afet Terimleri Sözlüğü, https://www.afad.gov.tr/upload/Node/3495/xfiles/sozluk.pdf, [Erişim 03 Haziran 2017].

Ekşi A., (2015), Kitlesel Olaylarda Hastane Öncesi Acil Sağlık Hizmetleri, Kitapana Yayınları, İzmir, 312ss.

Erkal T., Değerliyurt M., (2009), Türkiye'de afet yönetimi, Doğu Coğrafya Dergisi, 14(22), 147-164.

Ertürkmen C., (2006), Afet yönetimi, Yüksek Lisans Tezi, Ankara Üniversitesi Sosyal Bilimler Enstitüsü, Ankara.

Eryılmaz M., Dizer U., (2007), Afet Tibbı Cilt-I, Ünsal Yayınları, Ankara, 831ss.

Kadığlu M., Özdamar E., (2008), Afet zararlarını azaltmanın temel ilkeleri, T.C. İçişleri Bakanlığı Japonya Uluslararası İşbirliği Ajansı (JICA), JICA Yayın Ofisi, Birinci Bask1, Ankara, 368ss.

Kadığlu, M., (2008), Modern bütünleşik afet yönetimin temel ilkeleri, Kadığlu, M. ve Özdamar, E., (editörler), “Afet Zararlarını Azaltmanın Temel İlkeleri”, JICA Türkiye Ofisi Yayınları No: 2, Ankara, 42ss.

Macit İ., (2016), Bütünleşik Afet Yönetiminde Boyce-Codd Form Yöntemi ile GLIDE İ̧̧erikli Veritabanı Oluşturulması, Çukurova Üniversitesi Mühendislik Mimarlık Fakültesi Dergisi, 31(1), 191-202.

Özmen B., Nurlu M., Kuterdem K., Temiz A., (2005), Afet yönetimi ve afet işleri genel müdürlüğü, Deprem Sempozyumu, 23-25 Mart, Kocaeli.

Taştan B., Aydınoğlu A.Ç., (2015), Çoklu Afet Risk Yönetiminde Tehlike ve Zarar Görebilirlik Belirlenmesi İçin Gereksinim Analizi, Marmara Coğrafya Dergisi, 31, 366-397.

Türkdemir A.H., (2016), Triaj, http://docs.neu.edu.tr/staff/gurkan.ozel/56_2.pdf, [Erişim 03 Haziran 2017].

URL-1, (2017), http://www.ahder.org/definiciones/afet-yonetimi-nedir, [Ërişim 03 Haziran 2017].

URL-2, (2017), http://kisi.deu.edu.tr/yunusemre.ozer/AFET\%20YONETIMI.ppt, [Erişim 05 Haziran 2017].

URL-3, (2017), https://training.fema.gov/emiweb/is/is235b/is235b.pdf [Erişim 26 Temmuz 2017]. 
URL-4, (2017), http://www.medak.org.tr/faydali-bilgiler/faydali-bilgiler, [Erişim 04 Haziran 2017].

URL-5, (2017), https://sbu.saglik.gov.tr/Ekutuphane/kitaplar/afetlerdesaglikhizmetleriyonetimi.pdf, [Erişim 29 Mayıs 2017].

URL-6, (2017), http://www.disaster.qld.gov.au/About_disaster_management/Pages/Disaster-management-phases.aspx, [Erişim 02 Temmuz 2017].

URL-7, (2017), http://restoreyoureconomy.org/disaster-overview/phases-of-disaster/ [Erişim 02 Temmuz 2017].

URL-8, (2017), http://ayayder.org/tr-TR/kose-yazilari/268/olay-yeri-yonetimi-ve-triaj, [Erişim 02 Haziran 2017].

URL-9, (2017), http://file.atuder.org.tr/_atuder.org/fileUpload/IvLnVztWjsJg.pdf, [Erişim 02 Haziran 2017].

URL-10, (2017), http://www.megep.meb.gov.tr/mte_program_modul/moduller_pdf/Triaj.pdf, [Erişim 07 Haziran 2017].

Yavaş H., (2001), Doğal Afet Yönetimi ve Yerel Gündem 21 Çalışmaları Kapsamında İzmir'de Deprem Riski, Dokuz Eylül Üniversitesi Sosyal Bilimler Enstitüsü Dergisi, 3(3), 118-138. 